University of Nebraska - Lincoln

DigitalCommons@University of Nebraska - Lincoln

Biological Systems Engineering: Papers and

Publications

Biological Systems Engineering

2011

\title{
Comparison of subsurface and surface runoff phosphorus transport rates in alluvial floodplains
}

\author{
Aaron R. Mittelstet \\ Oklahoma State University, Stillwater, amittelstet2@unl.edu \\ Derek M. Heeren \\ University of Nebraska-Lincoln, derek.heeren@unl.edu \\ Garey A. Fox \\ Oklahoma State University - Main Campus, gafox2@ncsu.edu \\ Daniel E. Storm \\ Oklahoma State University - Main Campus, dan.storm@okstate.edu \\ Michael J. White \\ USDA Agricultural Research Service, Grassland Soil and Water Research Laboratory, Temple, TX, \\ mike.white@ars.usda.gov
}

See next page for additional authors

Follow this and additional works at: https://digitalcommons.unl.edu/biosysengfacpub

Part of the Biological Engineering Commons

Mittelstet, Aaron R.; Heeren, Derek M.; Fox, Garey A.; Storm, Daniel E.; White, Michael J.; and Miller, Ronald B., "Comparison of subsurface and surface runoff phosphorus transport rates in alluvial floodplains" (2011). Biological Systems Engineering: Papers and Publications. 222.

https://digitalcommons.unl.edu/biosysengfacpub/222

This Article is brought to you for free and open access by the Biological Systems Engineering at DigitalCommons@University of Nebraska - Lincoln. It has been accepted for inclusion in Biological Systems Engineering: Papers and Publications by an authorized administrator of DigitalCommons@University of Nebraska Lincoln. 
Authors

Aaron R. Mittelstet, Derek M. Heeren, Garey A. Fox, Daniel E. Storm, Michael J. White, and Ronald B. Miller 


\title{
Comparison of subsurface and surface runoff phosphorus transport rates in alluvial floodplains
}

\author{
Aaron R. Mittelstet ${ }^{a}$, Derek M. Heeren ${ }^{a}$, Garey A. Fox ${ }^{a, *}$, Daniel E. Storm ${ }^{a}$, Michael J. White ${ }^{b}$, \\ Ronald B. Miller ${ }^{\mathrm{a}}$ \\ a Oklahoma State University, Department of Biosystems and Agricultural Engineering, 111 Agricultural Hall, Stillwater, OK 74078, USA \\ ${ }^{\mathrm{b}}$ USDA Agricultural Research Service, Grassland Soil and Water Research Laboratory, Temple, TX, USA
}

\section{A R T I C L E I N F O}

\section{Article history:}

Received 2 November 2010

Received in revised form 29 March 2011

Accepted 6 April 2011

Available online 4 May 2011

\section{Keywords:}

Alluvial floodplains

Hydrologic modeling

Phosphorus management

Preferential flow

Subsurface transport

\begin{abstract}
A B S T R A C T
Phosphorus (P) loading to streams can occur by both surface runoff and subsurface transport, with subsurface $P$ transport often assumed negligible. Groundwater P concentrations in alluvial aquifers can be significant, especially in preferential flow paths (PFPs). The objectives of this research were to quantify subsurface $\mathrm{P}$ transport rates at two sites in northeastern Oklahoma and to compare them with surface runoff $P$ transport rates derived from a hydrologic model, the Pasture Phosphorus Management Calculator (PPM Plus). Ozark ecoregion study sites were adjacent to the Barren Fork Creek and Honey Creek in northeastern OK, USA. Each site, instrumented with 24 observation wells, was monitored for several months for both groundwater levels and P concentrations. Using the flow and P concentration data, Monte Carlo simulations with Darcy's Law and a P transport rate equation were used to calculate the distributions of subsurface $P$ transport rates across a transect within the well field containing a single identified PFP. Total subsurface $\mathrm{P}$ transport rates, through both the non-PFP flow domain and a single PFP, were estimated to be $0.04 \mathrm{kgyear}^{-1}$ and $0.03 \mathrm{~kg} y e a r^{-1}$ for the Barren Fork Creek and Honey Creek field sites, respectively. Monte Carlo simulations for surface runoff P transport rates with PPM Plus resulted in average total P surface runoff transport rates of $0.07 \mathrm{~kg} \mathrm{year}^{-1}$ for the Barren Fork Creek site and $0.08 \mathrm{~kg} \mathrm{year}^{-1}$ for the Honey Creek site. For the groundwater at these floodplains, the P source was P-laden stream water flowing into the alluvial aquifer and a minimal quantity of $P$ leaching from the surface. Results indicated that the subsurface P transport rates for small ( $3 \mathrm{ha}$ ) alluvial floodplain sites in the Ozark ecoregion were at least $0.03-0.04 \mathrm{~kg}_{\text {year }}{ }^{-1}$, although subsurface $\mathrm{P}$ transport rates may be higher in cases with greater numbers of PFPs and where the subsurface is connected to a larger P source.
\end{abstract}

(C) 2011 Elsevier B.V. All rights reserved.

\section{Introduction}

Phosphorus $(\mathrm{P})$ is a necessary nutrient for terrestrial and aquatic plants, yet over-application of organic and/or inorganic fertilizers to agricultural fields can result in elevated soil test phosphorus (STP) levels and can lead to eutrophication in receiving streams and reservoirs (Daniel et al., 1998). One such area of concern is eastern Oklahoma and western Arkansas (White et al., 2009; Andrews et al., 2009) where poultry litter is often applied based on nitrogen requirements, resulting in excessive $\mathrm{P}$ application. Sharpley et al. (2003) noted that feed imported to support concentrated poultry production has resulted in a net increase of nutrients in

\footnotetext{
* Corresponding author. Tel.: +1 405744 8423; fax: +1 4057446059. E-mail addresses: aaron.mittelstet10@okstate.edu (A.R. Mittelstet), derek.heeren@okstate.edu (D.M. Heeren), garey.fox@okstate.edu (G.A. Fox), dan.storm@okstate.edu (D.E. Storm), mike.white@ars.usda.gov (M.J. White), ron.miller@okstate.edu (R.B. Miller).
}

the region. After export of poultry products, what remains in the region is nutrient rich poultry litter, which is bulky and expensive to export. Therefore, the poultry litter is often applied to nearby pastures, including those in floodplains, as an inexpensive fertilizer. Over time excessive application can result in elevated STP with an increased potential for $\mathrm{P}$ transport to streams and reservoirs.

Nonpoint source P pollution became a major focus in the 1970 s and 1980s after it was discovered that reducing point source pollution did not significantly improve water quality in many watersheds (Crowder and Young, 1988). Compared to point source load reduction, nonpoint source load reduction is much more difficult and complex (Sims and Sharpley, 2005). The design and implementation of agricultural conservation practices to reduce $\mathrm{P}$ in runoff, such as buffer strips, riparian zones, terracing, and cover crops, are site specific and may be difficult to implement as economic, social, and political considerations affect farmers' willingness to adopt and maintain these practices (Sharpley et al., 2003; Sims and Sharpley, 2005). As in the 1970s and 1980s when the focus was on the easily measurable and reducible point 
(a)

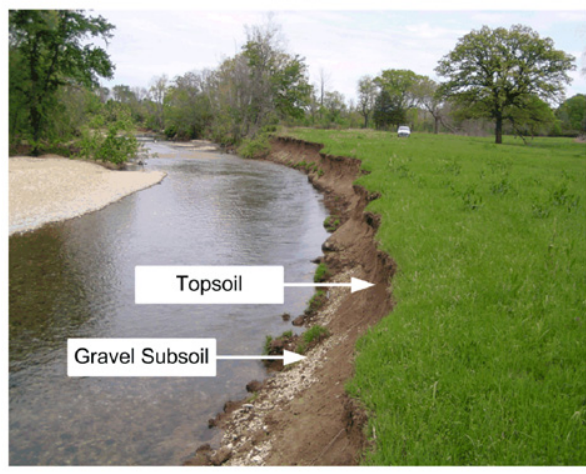

Southeast (b)

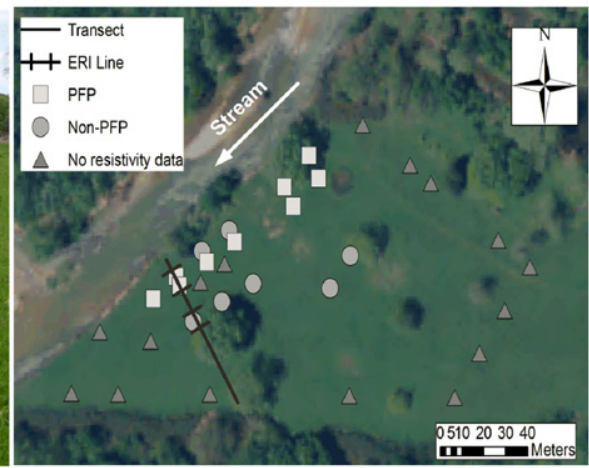

(c)

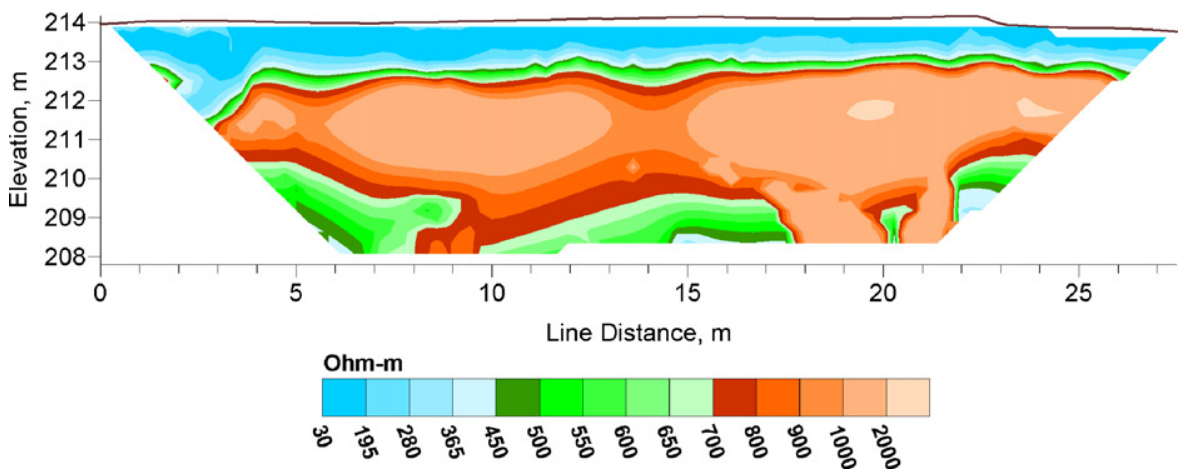

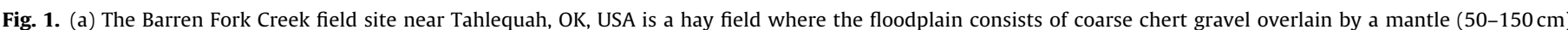

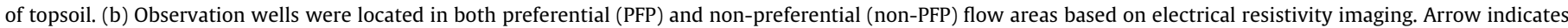

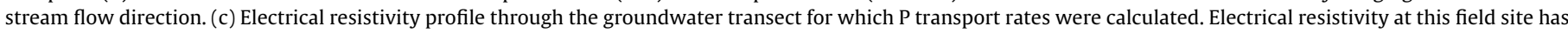
been positively correlated to saturated hydraulic conductivity (Miller et al., 2010).

sources, implementation of riparian buffer zones and other conservation practices currently focus on the more easily understood and observed surface runoff mechanism (Lacas et al., 2005; Popov et al., 2005; Reichenberger et al., 2007; Poletika et al., 2009; Sabbagh et al., 2009). Although conservation practices can reduce P loss in surface runoff, the movement of subsurface $P$ and its contribution to the receiving stream system may also need to be considered. Studies have shown that subsurface nutrient transport can be significant in soils with preferential flow pathways (PFPs) (McCarty and Angier, 2001; Polyakov et al., 2005; Fuchs et al., 2009; Heeren et al., 2010, in press) and limited soil sorption capacity (Carlyle and Hill, 2001; Polyakov et al., 2005).

Subsurface $P$ transport from agricultural fields with tile drainage is well documented (Sims et al., 1998; Stamm et al., 1998; Heathwaite and Dils, 2000; Kleinman et al., 2004), but the research on subsurface $\mathrm{P}$ transport in other contexts is less developed (Gachter et al., 1998; Turner and Haygarth, 2000; Djodjic et al., 2004; Nelson et al., 2005). For example, from research on four grassland soils, Turner and Haygarth (2000) documented that subsurface $\mathrm{P}$ transport, primarily in the dissolved form, can occur at concentrations that could cause eutrophication. When assessing long-term risk of $\mathrm{P}$ loss from waste-amended soils, Nelson et al. (2005) indicated that P leaching and subsurface transport should be considered.

There have been studies conducted in which observation wells were used to monitor the movement of $\mathrm{P}$ in alluvial floodplains under natural conditions (Vanek, 1993; Cooper et al., 1995; Carlyle and Hill, 2001; Thompson and McFarland, 2010). Studies have shown high $\mathrm{P}$ availability for groundwater transport due to $\mathrm{P}$ saturation of the riparian zone (Cooper et al., 1995) and near streambank sediment (Thompson and McFarland, 2010). Mon- itoring 12 wells in a lake riparian zone, Vanek (1993) noted groundwater $\mathrm{P}$ concentrations ranging from 0.4 to $11 \mathrm{mg} \mathrm{L}^{-1}$ with an average of $2.6 \mathrm{mg} \mathrm{L}^{-1}$. Carlyle and Hill (2001) monitored the behavior of $\mathrm{P}$ in the subsurface in a river riparian zone and suggested that riparian areas can become saturated with $P$. They documented higher soluble reactive P (SRP) concentrations (0.10-0.95 $\left.\mathrm{mg} \mathrm{L}^{-1}\right)$ in areas having soils with higher hydraulic conductivities buried under topsoils. Due to the changes in redox potential, they suggested that riparian areas might actually be contributing to the release of $\mathrm{P}$ to subsurface flow (Carlyle and Hill, 2001).

A growing body of research addresses $P$ transport in the Ozark ecoregion, which is characterized by gravel bed streams and coarse gravel alluvial aquifers overlain with a mantle $(1-300 \mathrm{~cm})$ of silt loam. Storm et al. (2009), using the Soil and Water Assessment Tool (SWAT) (Arnold et al., 1998) to model the Illinois River basin in eastern Oklahoma and western Arkansas, estimated that of the entire nonpoint source P load to Lake Tenkiller, 7\% was derived from baseflow contributions compared to $22 \%$ from poultry litter via surface runoff contributions. On an alluvial floodplain site along the Barren Fork Creek, Fuchs et al. (2009) used a trench to inject P into the groundwater flow system and found it to be rapidly transported in a PFP with minimal attenuation. Heeren et al. (2010) used geophysical methods to characterize the PFP as a buried gravel bar, and performed a larger scale tracer test that demonstrated the impact of the subsurface physical heterogeneities on solute transport.

The objectives of this research were to utilize groundwater table elevation, STP, and subsurface P concentration data from the Barren Fork Creek and Honey Creek floodplain sites in northeastern Oklahoma to (1) quantify distributions in subsurface P transport 
(a)

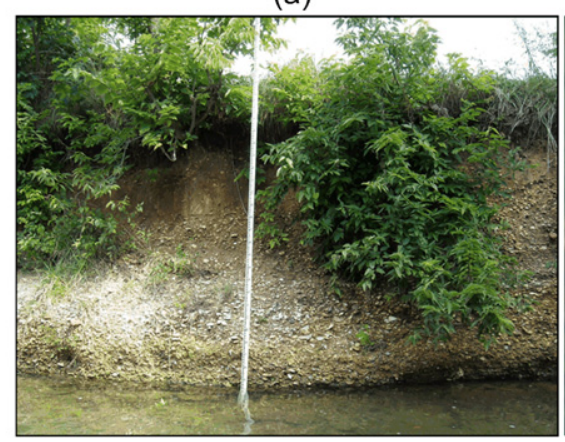

(b)

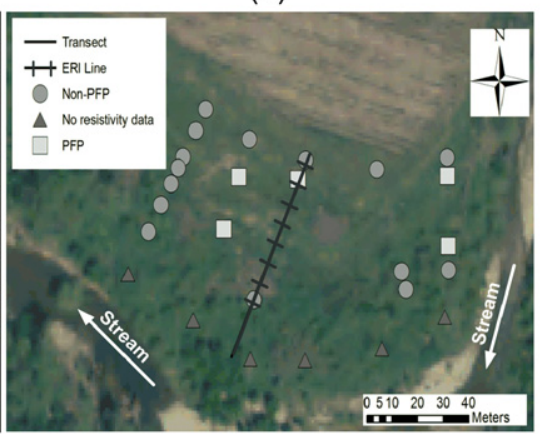

(c)

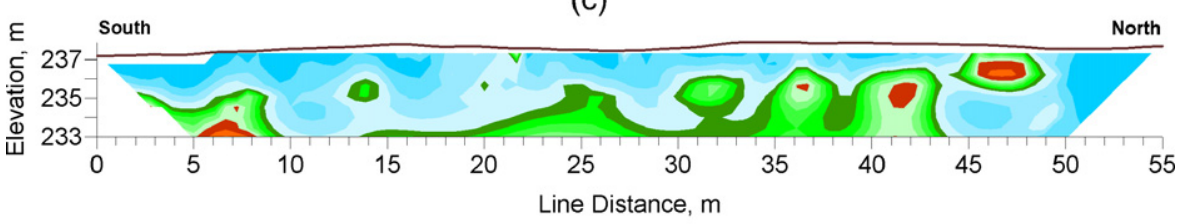

Ohm-m
North

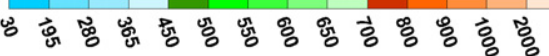

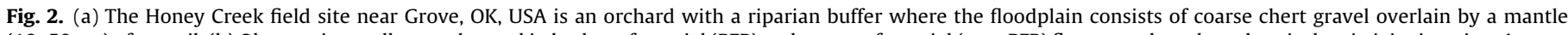

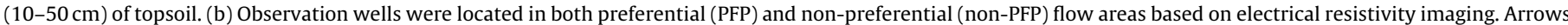

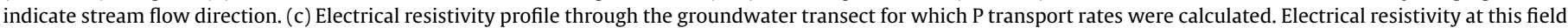
site has been positively correlated to saturated hydraulic conductivity (Miller et al., 2010).

rates across a transect within the well field in both PFP and non-PFP domains using Monte Carlo simulations, (2) to estimate distributions of surface runoff $P$ transport rates based on Monte Carlo simulations of the Pasture Phosphorus Management Calculator (PPM Plus) (White et al., 2009, 2010), and (3) to compare the subsurface and surface runoff $P$ transport rates at each site.

\section{Materials and methods}

\subsection{Barren Fork Creek and Honey Creek floodplain sites}

The two floodplain sites were located in the Ozark ecoregion of northeastern Oklahoma. The Barren Fork Creek (Fig. 1, latitude: $35.90^{\circ}$, longitude: $-94.85^{\circ}$ ) and Honey Creek sites (Fig. 2, latitude: $36.54^{\circ}$, longitude: $-94.70^{\circ}$ ) were immediately downstream of U.S. Geological Survey (USGS) gage stations 07197000 and 07189542 , respectively. With a watershed size of $845 \mathrm{~km}^{2}$, the Barren Fork Creek site had a median daily flow of $3.6 \mathrm{~m}^{3} \mathrm{~s}^{-1}$ and was a fourth order stream. Honey Creek, a third order stream, had a $0.54 \mathrm{~m}^{3} \mathrm{~s}^{-1}$ median daily flow and a $150 \mathrm{~km}^{2}$ watershed. Both floodplain sites consisted of alluvial gravel deposits underlying a mantle of topsoil (Razort gravelly loam). The Barren Fork site's topsoil thickness ranged from 0.5 to $1.5 \mathrm{~m}$ (Fig. 3). The alluvial floodplain consisted of a hay field with no fertilizer applied in recent years and had an area of 2.7 ha with a $0.004 \%$ slope. The Honey Creek site had a topsoil thickness ranging from 0.1 to $0.5 \mathrm{~m}$ (Fig. 3) and had not received poultry litter application for over 10 years. The site had a $0.01 \%$ slope and a total area of $3.2 \mathrm{ha}$, of which 1.5 ha was forest along the stream and the remainder was a hay field.

\subsection{Soil sampling}

The STP levels in the soils were quantified by collecting $15-\mathrm{cm}$ soil cores from approximately 30 locations within each of the floodplain sites. These 30 soil cores were composited, mixed, and three subsamples were analyzed for STP by the Soil, Water, and Forage Analytical Laboratory at Oklahoma State University. Testing con-

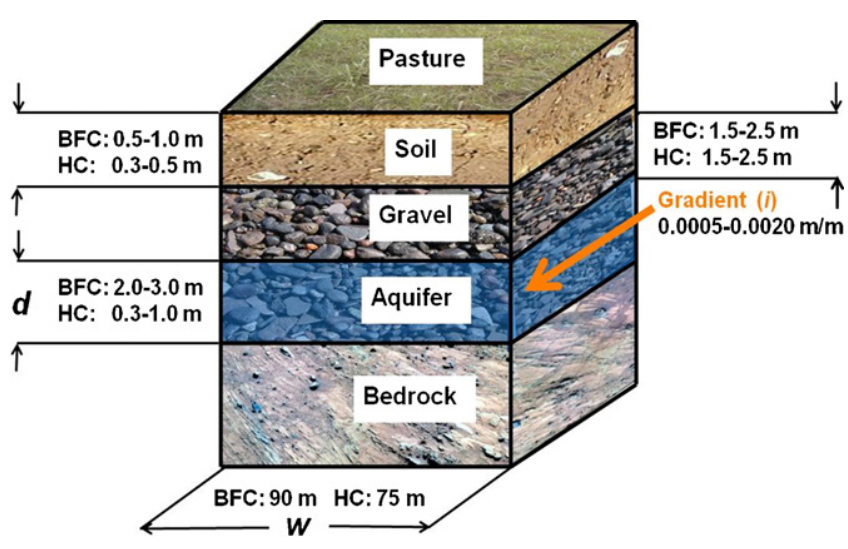

Fig. 3. Typical soil profile at the Barren Fork Creek (BFC) and Honey Creek (HC) alluvial floodplain sites. Preferential flow paths (PFP) become activated as the water table rises due to an influx of stream water during high flow events.

sisted of adding $20 \mathrm{~mL}$ of Melich 3 extraction to $2 \mathrm{~g}$ soil samples, shaking for $5 \mathrm{~min}$, filtering, and then analyzing for $\mathrm{P}$ with inductively coupled plasma spectrometry (ICP).

\subsection{Water levels and subsurface P sampling}

Based on previous geophysical research (Heeren et al., 2010, in press; Miller et al., 2010), 24 observation wells were installed at each site. Geophysics has been widely used for subsurface mapping (Pellerin, 2002; Robinson et al., 2008). Resistivity mapping involves measuring the electrical properties of near-surface earth materials, which vary with grain size, mineral type, solute content of pore water, and pore-space saturation. Electrical resistivity is calculated at several locations in a two-dimensional profile by carefully measuring the voltage of a known electrical current between two electrodes in contact with the soil. Miller et al. (2010) collected electrical resistivity data using a SuperSting R8/IP Earth Resistivity Meter (Advanced GeoSciences Inc., Austin, TX) with a 56-electrode 
array (see Figs. 1 and 2c for examples). The profiles employed electrode spacings of $0.5-2.5 \mathrm{~m}$ with associated depths of investigation ranging from 7.5 to $25.0 \mathrm{~m}$, respectively. The resistivity sampling and subsequent inversion utilized a proprietary routine devised by Halihan et al. (2005), which produced higher resolution images than conventional techniques.

Using a vadose zone borehole permeameter designed for coarse gravel (Miller et al., in press), a positive correlation between electrical resistivity and hydraulic conductivity was established for the Barren Fork Creek and Honey Creek floodplain sites (Miller et al., 2010). Based on that correlation and the previous electrical resistivity results (Heeren et al., 2010, in press; Miller et al., 2010), observation wells were located in both high hydraulic conductivity (one or more possible preferential flow pathways or PFPs) and low hydraulic conductivity (non-PFP) subsoils (Figs. 1 and 2b). In this research, a PFP is defined as a region of high hydraulic conductivity in the vadose zone that has potential for rapid transport of water and solutes when saturated by a high water table.

A Geoprobe Systems drilling machine (6200 TMP, Kejr Inc., Salina, KS) was used to install observation wells in the alluvial floodplains with a 2.0-3.0 m screened section at the base. Depth to refusal for installed wells ranged from $4.0 \mathrm{~m}$ to greater than $5.0 \mathrm{~m}$ at the Barren Fork Creek site and from 2.5 to $3.5 \mathrm{~m}$ at the Honey Creek site. Bentonite clay was placed at the top of the well casing to prevent surface runoff from entering the borehole.

Observation wells were instrumented with automated water level loggers (HoboWare, Onset Computer Corp., Cape Cod, MA) to monitor water pressure and temperature at $5 \mathrm{~min}$ intervals. One logger was placed above the water table at each site to account for changes in atmospheric pressure. Reference water table elevations, obtained with a water level indicator, were then calculated. The logger data were processed with HoboWare Pro software, which accounted for changes in atmospheric pressure as well as changes in water density due to temperature. Contour plots of water table elevation were generated with MATLAB (The Mathworks, Natick, MA) (Fig. 4a and c). The local USGS gage stations were used to analyze stream stage.

Using a peristaltic pump, water samples were collected from the stream and observation wells during both baseflow and high flow events (Table 1), preserved on ice, and transported back to the laboratory for analysis. High flow events were of particular interest because stream $P$ concentrations generally increase with streamflow in these watersheds (Andrews et al., 2009). The samples were digested based on the sulfuric acid-nitric acid method (Pote et al., 2009), and total P concentrations were determined colorimetrically (Murphy and Riley, 1962; EPA Method 365.2) with a spectrophotometer (Spectronic 21D, Milton Roy, Ivyland, PA). Contour plots of total $P$ concentration were generated with MATLAB (The Mathworks, Natick, MA) (Fig. 4b and d). More details of water level monitoring and $\mathrm{P}$ results are presented in Heeren et al. (in press).

\subsection{Subsurface phosphorus transport rates}

At each site, one of the electrical resistivity lines that identified a PFP was chosen as the transect (extended to the boundary of the well field) across which transport rates were calculated (Figs. 1 and 2). The subsurface $P$ transport rate was defined as the average annual subsurface $P$ rate crossing the selected transect within the observation well field. Subsurface $P$ transport rate was calculated by first determining the average groundwater flow based on Darcy's Law:

$Q=q A=-K \frac{\partial h}{\partial x} w d=|K i| w d$ where $Q$ is the groundwater discharge $\left(\mathrm{L}^{3} \mathrm{~T}^{-1}\right), q$ is the Darcy velocity $\left(\mathrm{LT}^{-1}\right), h$ is the groundwater head (L), $x$ is the distance along the direction of flow $(\mathrm{L}), A$ is the cross-sectional area $\left(\mathrm{L}^{2}\right), w$ is the width of the monitored transect or groundwater flow domain (L), $d$ is the depth of the aquifer (L), and $i$ is the average groundwater gradient $\left(\mathrm{LL}^{-1}\right)$. Note that this equation was applied separately to a single, identified PFP and the remaining non-PFP groundwater domains within the selected transect, using the site specific width $(w)$ and depth $(d)$ of each domain. The annual subsurface $P$ transport rate, $m_{p}\left(\mathrm{M} \mathrm{T}^{-1}\right)$, was then calculated using the following mass transport equation:

$m_{P}=Q \times T P \times n_{d}$

where TP is the total P concentration $\left(\mathrm{ML}^{-3}\right)$ measured from observation wells in the PFP and non-PFP domains, and $n_{d}$ is the number of days per year in which each groundwater flow domain was activated.

A Monte Carlo simulation was performed using 10,000 realizations of subsurface $P$ transport rates due to uncertainty in six variables, with the distributions and statistics shown in Table 2. Following McKay (1995) and Fox et al. (2010), a uniform distribution was used for input parameters with an absence of experimental values to inform a probability distribution. A normal distribution after a Box Cox transformation was used to quantify $K$ throughout the observation well field, based on electrical resistivity measurements correlated to point measurements of $K$ as reported in Miller et al. (2010, in press). At the Barren Fork Creek site, subsoils with electrical resistivity values greater than $700 \Omega-\mathrm{m}$ (correlating to a hydraulic conductivity of $74 \mathrm{~m} \mathrm{day}^{-1}$ ) were considered to be a PFP. At the Honey Creek floodplain, which is a smaller scale alluvial system, an electrical resistivity of $500 \Omega$-m (correlating to a hydraulic conductivity of $53 \mathrm{~m} \mathrm{day}^{-1}$ ) was considered to be the demarcation between PFP and non-PFP subsoils. The aquifer width, $w$, was held constant for each field site for the non-PFP domain, but varied for the PFP domain assuming a uniform distribution. The $w$ of the PFP was based on the identification of the PFP within ERI data for the transect at each site (Figs. 1 and 2c). The distribution for $d$ was assumed uniform for both PFP and non-PFP domains. The ranges in $d$ for the non-PFP domains were identified based on typical baseflow water table elevations combined with depth to refusal during well installation and electrical resistivity mapping at each field site as reported in Miller et al. (2010). The ranges in $d$ for PFPs were determined based on the high $K$ zones in the ERI data for each transect (Figs. 1 and 2c).

The non-PFP domain was assumed active for 365 days; therefore, a fixed value was used for these calculations. The PFP activity was quantified based on the minimum mean daily flow that resulted in PFP activation during the study period, which is shown for each site in Fig. 4. P can be seen preferentially entering the aquifer at point $(90 \mathrm{~m}, 70 \mathrm{~m})$ at the Barren Fork Creek site (Fig. 4b) and at point $(230 \mathrm{~m}, 110 \mathrm{~m})$ at the Honey Creek site (Fig. $4 \mathrm{~d}$ ). While the impacts of the PFPs are not visible in the flow data at these particular times (Fig. 4a and c), the PFPs (identified in electrical resistivity data) must be activated as evidenced by the high $\mathrm{P}$ concentrations. The requirements for PFP activation were the mean daily flows at these sampling times (Table 1), which were 35 and $4.2 \mathrm{~m}^{3} \mathrm{~s}^{-1}$ for the Barren Fork Creek and Honey Creek field sites, respectively. The lognormal $n_{p}$ parameter distribution was derived from 60 years and 12 years of daily mean streamflow measurements by the USGS at the Barren Fork Creek and Honey Creek sites, respectively. The P transport rate was highly dependent on $n_{d}$. Uniform distributions were used for $i$ and TP with unique $i$ and TP for the PFPs and non-PFPs. The $i$ and TP distributions were derived from groundwater levels and $P$ concentrations measured in the observation well fields as well as particular PFPs (Fig. 4) with generally 

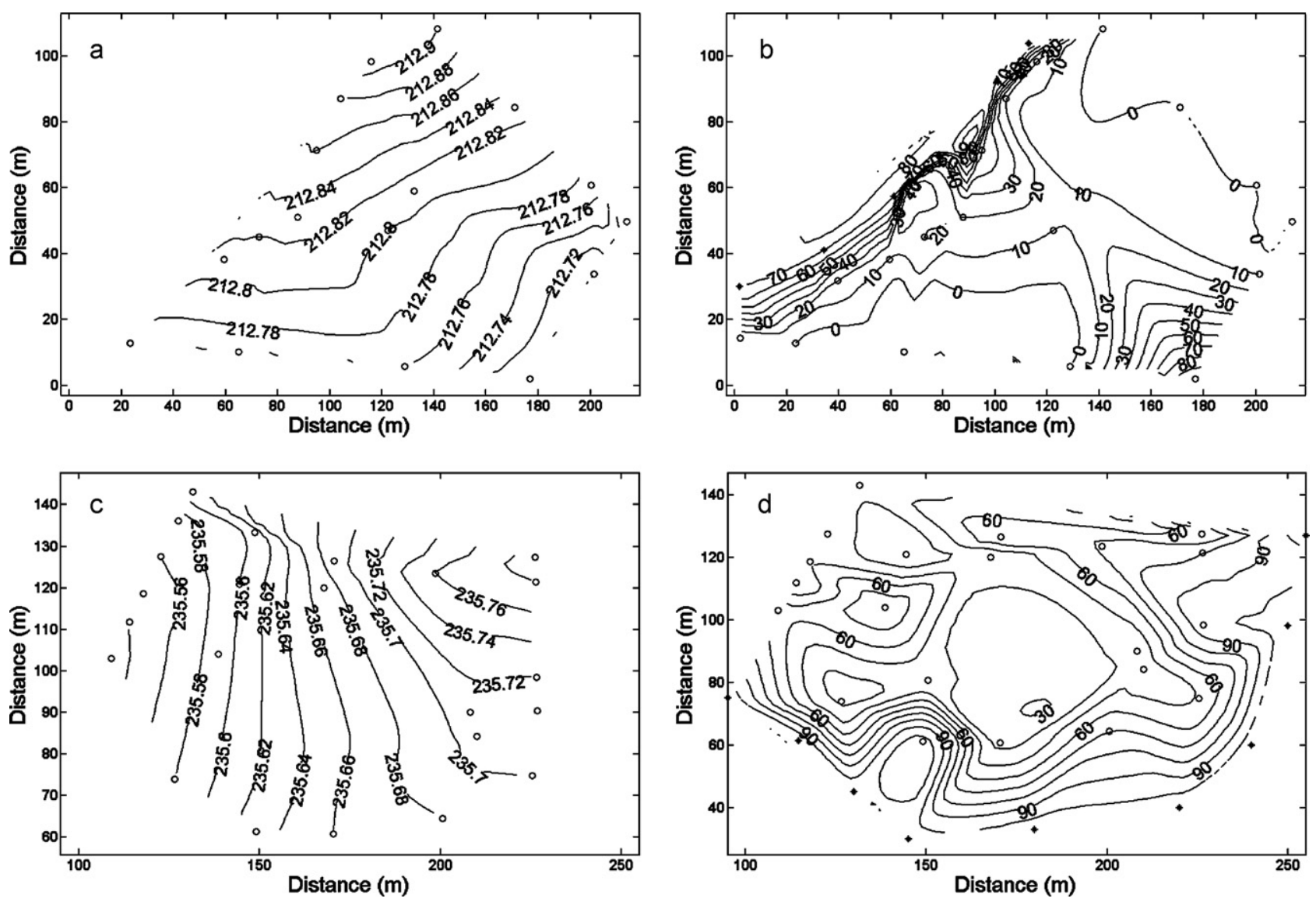

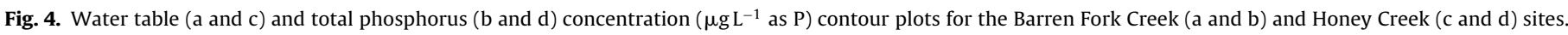

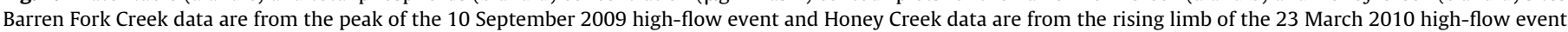
Interpolations are based on measured data from wells (circles) and the stream (stars).

Figures are adapted from Heeren et al. (in press).

Table 1

Stream flow data and groundwater total phosphorus concentrations ( $\mu \mathrm{g} \mathrm{L}^{-1}$ as P) for PFP and non-PFP wells for each sampling time during the study period.

\begin{tabular}{|c|c|c|c|c|c|c|}
\hline \multirow[t]{2}{*}{ Site } & \multirow[t]{2}{*}{ Date (month/day/year) } & \multirow[t]{2}{*}{ Time } & \multirow[t]{2}{*}{ Hydrograph position } & \multirow[t]{2}{*}{ Mean daily flow $\left(\mathrm{m}^{3} \mathrm{~s}^{-1}\right)$} & \multicolumn{2}{|c|}{ Median total P concentration } \\
\hline & & & & & $\operatorname{PFP}\left(\mu g L^{-1}\right)$ & Non-PFP $\left(\mu \mathrm{g} \mathrm{L}^{-1}\right)$ \\
\hline \multirow{8}{*}{ Barren Fork Creek $^{\mathrm{a}}$} & $9 / 10 / 09$ & $10: 00$ & Rising Limb & 35 & 30 & 20 \\
\hline & $9 / 10 / 09$ & 13:00 & Rising Limb & 35 & 20 & 10 \\
\hline & $9 / 10 / 09$ & $22: 00$ & Peak & 35 & 30 & 10 \\
\hline & $9 / 11 / 09$ & $10: 00$ & Falling Limb & 44 & 40 & 20 \\
\hline & $9 / 12 / 09$ & $14: 00$ & Falling Limb & 23 & 30 & 10 \\
\hline & $3 / 22 / 10$ & $12: 00$ & $\sim$ Rising Limb & 17 & 30 & 30 \\
\hline & $3 / 23 / 10$ & $15: 00$ & Falling Limb & 39 & 50 & 30 \\
\hline & $3 / 26 / 10$ & $12: 00$ & Falling Limb & 62 & 50 & 30 \\
\hline \multirow{5}{*}{ Honey Creek ${ }^{\mathrm{a}}$} & $10 / 09 / 09$ & $16: 00$ & Falling Limb & 41 & 40 & 50 \\
\hline & $10 / 15 / 09$ & $12: 00$ & Baseflow & 2.9 & 40 & 60 \\
\hline & $3 / 22 / 10$ & $18: 00$ & Rising Limb & 4.2 & 80 & 50 \\
\hline & $3 / 23 / 10$ & 9:00 & Peak & 5.5 & 40 & 60 \\
\hline & $3 / 26 / 10$ & $18: 00$ & Falling Limb & 9.2 & 40 & 50 \\
\hline
\end{tabular}

a Data adapted from Heeren et al. (in press).

higher $i$ and TP for the PFP domains due to their activation during storm events (Heeren et al., in press).

\subsection{Surface runoff phosphorus transport rates}

PPM Plus is a software tool which predicts P and sediment in runoff from agricultural fields in Oklahoma (White et al., 2009, 2010). Using a region-specific, 15-year weather period, PPM Plus predicts the average annual $P$ and sediment transport rates delivered to the nearest stream from a single agricultural field. PPM Plus was calibrated ( $R^{2}$ of 0.61$)$ and validated $\left(R^{2}\right.$ of 0.68$)$ using 283 field years of field scale data from several sites across the southern United States (Storm et al., 2007). The sites varied based on nutrient application, size, soil type, and STP levels.

A myriad of management options can be simulated by accounting for detailed field characteristics and land management. PPM Plus is based on the Soil and Water Assessment Tool (SWAT) (Arnold et al., 1998), a product of more than 30 years of model development by the U.S. Department of Agriculture, Agricultural Research Service. While models like SWAT are a valuable tool for highly trained 
Table 2

Statistics for input parameters used in the Monte Carlo simulations of subsurface P transport rates at the Barren Fork Creek (BFC) and Honey Creek (HC) field sites.

\begin{tabular}{|c|c|c|c|}
\hline Parameter & Site & Flow domain & Input distributions for Monte Carlo ${ }^{a}$ \\
\hline \multirow[t]{2}{*}{ Saturated hydraulic conductivity $\left(\mathrm{m} \mathrm{day}^{-1}\right)$} & $\mathrm{BFC}$ & $\begin{array}{l}\text { Non-PFP } \\
\text { PFP }\end{array}$ & $\begin{array}{l}\text { Normal after power function }\left(\lambda^{\mathrm{b}}=-0.62\right) ; \mu_{x}{ }^{\mathrm{c}}=0.13 ; \sigma_{x}{ }^{\mathrm{c}}=0.04 \\
\text { Normal after power function }(\lambda=-0.62) ; \mu_{x}=0.13 ; \sigma_{x}=0.04\end{array}$ \\
\hline & $\mathrm{HC}$ & $\begin{array}{l}\text { Non-PFP } \\
\text { PFP }\end{array}$ & $\begin{array}{l}\text { Normal after power function }(\lambda=0.23) ; \mu_{x}=2.3 ; \sigma_{x}=0.17 \\
\text { Normal after power function }(\lambda=0.23) ; \mu_{x}=2.3 ; \sigma_{x}=0.17\end{array}$ \\
\hline \multirow[t]{2}{*}{ Groundwater gradient $\left(\mathrm{m} \mathrm{m}^{-1}\right)$} & $\mathrm{BFC}$ & $\begin{array}{l}\text { Non-PFP } \\
\text { PFP }\end{array}$ & $\begin{array}{l}\text { Uniform; } \min =0.0005 ; \max =0.0015 \\
\text { Uniform; } \min =0.0005 ; \max =0.0015\end{array}$ \\
\hline & $\mathrm{HC}$ & $\begin{array}{l}\text { Non-PFP } \\
\text { PFP }\end{array}$ & $\begin{array}{l}\text { Uniform; } \min =0.0010 ; \max =0.0020 \\
\text { Uniform; } \min =0.0020 ; \max =0.0040\end{array}$ \\
\hline \multirow[t]{2}{*}{ Aquifer depth (m) } & $\mathrm{BFC}$ & $\begin{array}{l}\text { Non-PFP } \\
\text { PFP }\end{array}$ & $\begin{array}{l}\text { Uniform; } \min =2.0 ; \max =3.0 \\
\text { Uniform; } \min =2.0 ; \max =3.0\end{array}$ \\
\hline & $\mathrm{HC}$ & $\begin{array}{l}\text { Non-PFP } \\
\text { PFP }\end{array}$ & $\begin{array}{l}\text { Uniform; } \min =0.25 ; \max =1.0 \\
\text { Uniform; } \min =0.5 ; \max =2.0\end{array}$ \\
\hline \multirow[t]{2}{*}{ Domain width (m) } & $\mathrm{BFC}$ & $\begin{array}{l}\text { Non-PFP } \\
\text { PFP }\end{array}$ & $\begin{array}{l}\text { Fixed; } 65 \\
\text { Uniform; } \min =15 ; \max =20\end{array}$ \\
\hline & $\mathrm{HC}$ & $\begin{array}{l}\text { Non-PFP } \\
\text { PFP }\end{array}$ & $\begin{array}{l}\text { Fixed; } 75 \\
\text { Uniform; } \min =3.0 ; \max =4.0\end{array}$ \\
\hline \multirow[t]{2}{*}{ Total phosphorus concentration $\left(\mu \mathrm{g} \mathrm{L}^{-1}\right)$} & $\mathrm{BFC}$ & $\begin{array}{l}\text { Non-PFP } \\
\text { PFP }\end{array}$ & $\begin{array}{l}\text { Uniform; } \min =10 ; \max =40 \\
\text { Uniform; } \min =30 ; \max =90\end{array}$ \\
\hline & $\mathrm{HC}$ & $\begin{array}{l}\text { Non-PFP } \\
\text { PFP }\end{array}$ & $\begin{array}{l}\text { Uniform; } \min =20 ; \max =60 \\
\text { Uniform; } \min =60 ; \max =80\end{array}$ \\
\hline \multirow[t]{2}{*}{ Activity (day) } & $\mathrm{BFC}$ & $\begin{array}{l}\text { Non-PFP } \\
\text { PFP }\end{array}$ & $\begin{array}{l}\text { Fixed; } 365 \\
\text { Lognormal; } \mu_{x}=2.47 ; \sigma_{x}=0.91\end{array}$ \\
\hline & $\mathrm{HC}$ & $\begin{array}{l}\text { Non-PFP } \\
\text { PFP }\end{array}$ & $\begin{array}{l}\text { Fixed; } 365 \\
\text { Lognormal; } \mu_{x}=2.01 ; \sigma_{x}=1.03\end{array}$ \\
\hline
\end{tabular}

\footnotetext{
a Note that unique distributions were used for the preferential flow (PFP) and non-preferential flow (non-PFP) domains.

b $\lambda=$ exponent for the power transformation of the original distribution.

c $\mu_{x}, \sigma_{x}=$ mean and standard deviation for the normal and lognormal distributions.
}

specialists, their complexity becomes prohibitive for use by most conservation and nutrient management planners. PPM Plus was designed to simplify the operation of SWAT in order to put the predictive power of a proven water quality model into the hands of people who make daily decisions that affect water quality.

Due to its ease of use and applicability at a field scale, PPM Plus was selected to estimate the average annual P loss from the two field sites. PPM Plus was parameterized for the Barren Fork Creek and Honey Creek field sites for two scenarios (Table 3). The first scenario represented actual land use at each site: low intensity agricultural production for pasture without cattle grazing or poultry litter application. The only agricultural activity was hay removal scheduled for August. The second scenario was hypothetical but represented typical high-intensity agricultural production in the region. Stocking rates were simulated at 1.2 animal units (AU) per ha with a $6 \mathrm{Mg} \mathrm{ha}^{-1}$ poultry litter application rate in March to meet the nitrogen requirements for a $9000 \mathrm{~kg} \mathrm{ha}^{-1}$ forage yield goal (Zhang et al., 2009).

Due to uncertainty in several variables, a Monte Carlo simulation was performed with 10,000 realizations on six variables, which were selected due to their uncertainty and sensitivity (Table 4). As for the subsurface transport rate computations, a uniform distribution was used for input parameters with an absence of experimental values to inform a probability distribution. A triangular distribution was used for the measured STP; a uniform distribution was chosen for the other five variables. The average field slope was estimated from ArcGIS using the 2008 National Agricultural Imagery Program Mosaic (NRCS, 2009). The distribution was then taken as $\pm 10 \%$ of the calculated value. The maximum curve number $(\mathrm{CN})$ was the estimated CN for a Razort soil (hydrologic soil group B) (Soil Conservation Service, 1972) for pasture in good condition (Haan et al., 1994). The minimum CN was 30, based on historic field observations that runoff is only rarely generated on these floodplains with high infiltration rates, even during high intensity rainfall events. The distributions for P percolation coefficient (PPERCO), $P$ soil partitioning coefficient (PHOSKD), and the P sorption coefficient (PSP) were based on the SWAT recommended calibration range (Neitsch et al., 2002).

\section{Results and discussion}

As noted by Heeren et al. (in press), the assumptions of uniform, homogeneous stream/aquifer interaction and only localized near-streambed water exchanges were not relevant for the two studied alluvial floodplains (Fig. 4). The activity of preferential flow pathways depended on the elevation of the water table and the interaction between the stream and the groundwater. The average groundwater flow direction at each floodplain site changed considerably between baseflow and storm events, and the highest water table gradients in the alluvial aquifer occurred during the rising limb of the hydrographs, when the stream stage was rising most quickly. It appeared that preferential flow pathways acted as divergence zones, allowing stream water to quickly enter the groundwater system during rising limbs of streamflow hydrographs, or as flow convergence zones draining a large groundwater area during the falling limbs of streamflow hydrographs. At the Barren Fork Creek site, a PFP at point $(90 \mathrm{~m}, 70 \mathrm{~m}$ ) (Fig. $4 \mathrm{a}$ and b) was found to act as a divergence zone, allowing stream water to preferentially flow into the alluvial aquifer. A large convergence zone occurred at the Honey Creek site directing water through the subsurface near the northern boundary of the meander bend or the upper left corner of the well field (Fig. 4c and d). 
Table 3

PPM Plus inputs for high and low intensity agricultural production scenarios for the Barren Fork Creek and Honey Creek field sites.

\begin{tabular}{|c|c|c|}
\hline Input parameter & Barren Fork Creek & Honey Creek \\
\hline \multicolumn{3}{|l|}{ Common inputs } \\
\hline Land use & Pasture & Pasture \\
\hline Field area (ha) & 2.7 & 1.7 \\
\hline Riparian buffer area (ha) & 0 & 1.5 \\
\hline Riparian buffer width (m) & 0 & 53 \\
\hline Field slope length (m) & 120 & 120 \\
\hline Distance to stream (m) & 0 & 0 \\
\hline Bank full width (m) & 34 & 24 \\
\hline Soil type & Razort gravelly loam & Razort gravelly loam \\
\hline Forage type & Mixed warm and cool season grasses & Mixed warm and cool season grasses \\
\hline \multicolumn{3}{|c|}{ Low intensity agricultural production scenario } \\
\hline Grazing density $\left(\mathrm{AU}^{\mathrm{a}} \mathrm{ha}^{-1}\right)$ & 0 & 0 \\
\hline Management operation & Hay-August & Hay-August \\
\hline \multicolumn{3}{|c|}{ High intensity agricultural production scenario } \\
\hline Grazing density $\left(\mathrm{AU} \mathrm{ha}^{-1}\right)$ & 1.2 & 1.2 \\
\hline Grazing duration & $\begin{array}{l}365 \text { days with } \\
\text { supplemental feed }\end{array}$ & $\begin{array}{l}365 \text { days with } \\
\text { supplemental feed }\end{array}$ \\
\hline Forage management & Optimally managed & Optimally managed \\
\hline Fertilization & $6 \mathrm{Mg} \mathrm{ha}^{-1}$ poultry litter & $6 \mathrm{Mg} \mathrm{ha}^{-1}$ poultry litter \\
\hline & March 1 & March 1 \\
\hline
\end{tabular}

a $\mathrm{AU}=$ animal units.

Table 4

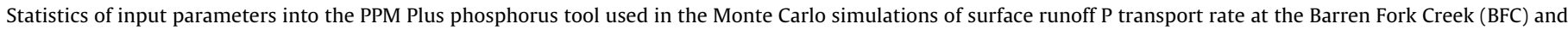
Honey Creek (HC) field sites.

\begin{tabular}{|c|c|c|}
\hline Site & Input parameter & Input distribution for Monte Carlo \\
\hline Barren Fork Creek & $\begin{array}{l}\text { Soil test phosphorus }\left(\mathrm{mg} \mathrm{kg}^{-1}\right) \\
\text { Curve number } \\
\text { Slope }\left(\mathrm{m} \mathrm{m}^{-1}\right) \\
\text { Phosphorus percolation coefficient } \\
\text { Phosphorus soil partitioning coefficient } \\
\text { Phosphorus sorption coefficient }\end{array}$ & $\begin{array}{l}\text { Triangular; } \min =28.5 ; \operatorname{mode}=29.5 ; \max =30.5 \\
\text { Uniform; } \min =30.0 ; \max =61.0 \\
\text { Uniform } \min =0.0036 ; \max =0.0044 \\
\text { Uniform; } \min =10.0 ; \max =17.0 \\
\text { Uniform; } \min =100 ; \max =300 \\
\text { Uniform; } \min =0.20 ; \max =0.60\end{array}$ \\
\hline Honey Creek & $\begin{array}{l}\text { Soil test phosphorus }\left(\mathrm{mg} \mathrm{kg}^{-1}\right) \\
\text { Curve number } \\
\text { Slope }\left(\mathrm{m} \mathrm{m}^{-1}\right) \\
\text { Phosphorus percolation coefficient } \\
\text { Phosphorus soil partitioning coefficient } \\
\text { Phosphorus sorption coefficient }\end{array}$ & $\begin{array}{l}\text { Triangular; } \min =51.5 ; \operatorname{mode}=53.0 ; \max =55.0 \\
\text { Uniform; } \min =30.0 ; \max =61.0 \\
\text { Uniform; } \min =0.009 ; \max =0.011 \\
\text { Uniform } \min =10.0 ; \max =17.5 \\
\text { Uniform; } \min =100 ; \max =300 \\
\text { Uniform; } \min =0.20 ; \max =0.60\end{array}$ \\
\hline
\end{tabular}

The floodplain STP levels at the Barren Fork site ranged between 28.5 and $30.5 \mathrm{mg} \mathrm{kg}^{-1}$ with an average of $29.5 \mathrm{mg} \mathrm{kg}^{-1}$ and standard deviation of $1.00 \mathrm{mg} \mathrm{kg}^{-1}$. The STP range at the Honey Creek site was $51.5-55.0 \mathrm{mg} \mathrm{kg}^{-1}$ with an average of $53.2 \mathrm{mg} \mathrm{kg}^{-1}$ and a standard deviation of $1.76 \mathrm{mg} \mathrm{kg}^{-1}$. The Honey Creek site possessed a higher average STP due to historical poultry litter applications on the floodplain. These STP levels suggested minimal P leaching through the topsoil layers in these floodplains; therefore, the main source of $\mathrm{P}$ measured in the observation wells was most likely from P-laden stream water entering the floodplain, an assertion supported by the groundwater elevation and $\mathrm{P}$ data.

As discussed in Heeren et al. (in press), water samples from observation wells were collected during multiple high flow events (Table 1 ) with peak flows from one to two orders of magnitude greater than median flow rates and were subsequently analyzed for total P concentrations (Fig. 4). During both baseflow and high flow conditions, groundwater P concentrations in the non-PFP domain were typically $10-40 \mu \mathrm{g} \mathrm{L}^{-1}$ and $20-60 \mu \mathrm{g} \mathrm{L}^{-1}$ at the Barren Fork Creek and Honey Creek field sites, respectively. It should be noted that some of the TP concentrations in the non-PFP wells at the Honey Creek site (Table 1) may be artificially elevated due to samples containing agitated sediment from the bottom of wells with very shallow water depths (wells furthest from the creek). The P concentrations were generally highest where stream water was entering the groundwater system and decreased with distance down-gradient from the stream. In activated PFPs, the P concentrations during high flow events were as high as $90 \mu \mathrm{g} \mathrm{L}^{-1}$ at the
Barren Fork Creek site and $80 \mu \mathrm{g} \mathrm{L}^{-1}$ at the Honey Creek field site. P can be seen preferentially entering the aquifer at point $(90 \mathrm{~m}, 70 \mathrm{~m})$ at the Barren Fork Creek site (Fig. $4 \mathrm{~b})$ and at point $(230 \mathrm{~m}, 110 \mathrm{~m})$ at the Honey Creek site (Fig. 4d). Potential PFPs were also observed at points $(180 \mathrm{~m}, 0 \mathrm{~m})$ and $(150 \mathrm{~m}, 60 \mathrm{~m})$ in the $P$ data at the Barren Fork Creek (Fig. 4b) and Honey Creek (Fig. 4d) sites, respectively.

Based on the Monte Carlo simulation of the subsurface P transport rate (Eqs. (1) and (2)), the estimated median annual subsurface $P$ transport rate for the non-PFP flow domain at the Barren Fork Creek field site was $0.04 \mathrm{~kg} y e a r^{-1}$ (Fig. 5a). This compared to a median of $0.003 \mathrm{~kg}$ year ${ }^{-1}$ from the single PFP. The median total $P$ transport rate from surface runoff based on the PPM Plus Monte Carlo simulations was $0.07 \mathrm{~kg}_{\text {year }}{ }^{-1}$ from the current conditions (low intensity scenario) and $9.9 \mathrm{~kg}_{\mathrm{year}}{ }^{-1}$ with litter application and cattle grazing (high intensity scenario). For the Honey Creek site, the estimated median annual subsurface $P$ transport rate was $0.03{\mathrm{~kg} y e a r^{-1}}$ in the non-PFP domain and $0.0004 \mathrm{~kg} \mathrm{year}^{-1}$ in the single PFP (Fig. 5b). These results compared to $0.08 \mathrm{~kg} \mathrm{year}^{-1}$ of surface $P$ runoff based on the low intensity scenario (low agricultural production) and $6.3 \mathrm{~kg}$ year $^{-1}$ of surface $P$ runoff based on the high intensity scenario (high agricultural production). The Honey Creek site had a smaller subsurface $P$ transport rate due to a smaller aquifer cross-sectional area (both in terms of $d$ and $w$ ) and $K$ compared to the Barren Fork Creek site. Also the size of the PFP was larger at the Barren Fork Creek site making the P transport rate higher than at Honey Creek. As stream order increases, $d$ and $K$ increase due to larger gravel deposits. Based on a Mann-Whitney 
(a) Barren Fork Creek

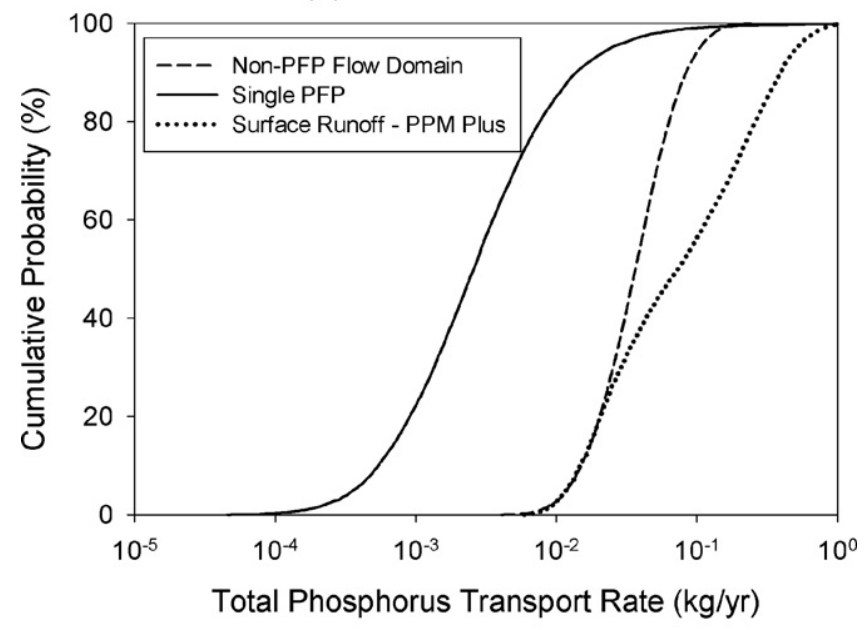

(b) Honey Creek

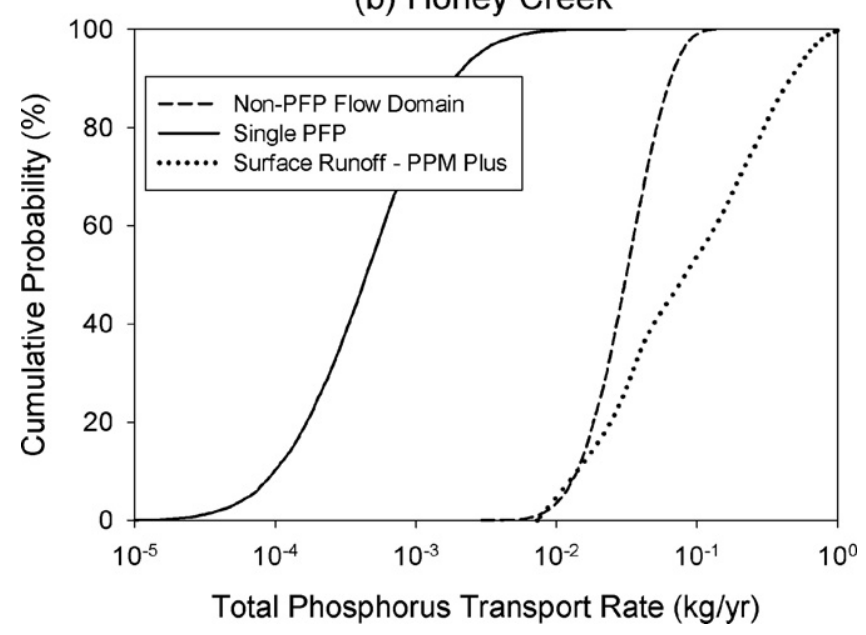

Fig. 5. Total phosphorus transport rate due to subsurface transport generated based on Monte Carlo analyses and total phosphorus transport rates in surface runoff based on PPM Plus simulations at the Barren Fork Creek and Honey Creek field sites under low intensity agricultural production. $\mathrm{PFP}=$ preferential flow pathway; non-PFP = non-preferential subsurface flow.

rank sum test, median values between the surface P transport rate and non-PFP subsurface $P$ transport rate were significantly different $(P<0.001)$ for both field sites.

The surface runoff $P$ transport rates based on the low and high agricultural production at the Barren Fork and Honey Creek sites from PPM Plus ranged from 0.03 to $3.6 \mathrm{~kg} \mathrm{ha}^{-1}$ year $^{-1}$ and were within the range of observed total P loss (0.02-4.6 $\left.\mathrm{kg} \mathrm{ha}^{-1} \mathrm{year}^{-1}\right)$ from previous studies at 12 field sites in eastern Oklahoma (Storm et al., 2007; White et al., 2009). The modeling results were also consistent with field measurements of total P loss observed by Romeis et al. (2011). They reported measured total P yields from commercial poultry-pasture headwater streams ranging from 0.03 to $3.17 \mathrm{~kg} \mathrm{ha}^{-1}$ over an $18-22$ months sampling period. They also summarized the range in $P$ yield $\left(0.1-17.8 \mathrm{~kg} \mathrm{ha}^{-1}\right.$ year $\left.^{-1}\right)$ from field-scale studies of $P$ transfer from poultry manure-amended pastures in the literature.

The subsurface P transport rate was on the same order of magnitude relative to the surface runoff $P$ transport rate for current site conditions, yet was small compared to the simulation with poultry litter application and cattle grazing. Though the total $P$ transport rate was small in the PFP due to the small area and number of active days, it may provide rapid unimpeded transport from the surface to the stream at high STP sites. In areas where there is a larger number of PFPs and/or during years where the PFP remains active for longer periods of time, the PFPs will provide a larger $P$ transport rate. For example, the $\mathrm{P}$ transport rate at the 99th percentile of the Monte Carlo simulation was $0.10 \mathrm{~kg}_{\text {year }}{ }^{-1}$ in the single PFP at the Barren Fork Creek, or $136 \%$ of the median surface runoff $P$ transport rate from low intensity conditions.

The Illinois River, of which the Barren Fork Creek is a tributary, may have a deeper aquifer, higher $K$, and larger PFPs, resulting in a higher subsurface $P$ transport rate. Therefore, as the stream order increases, the significance of subsurface P transport rates and PFPs may also increase. A need exists for additional research to scaleup the observations at these individual floodplains sites to the watershed scale, which will require future research at additional floodplain sites in larger-order stream systems. Of course, a difficulty that exists is identifying and documenting the number and size of PFPs within these alluvial floodplains. Geophysical techniques such as electrical resistivity imaging used by Miller et al. (2010) will be invaluable in future floodplain investigations.

These results also suggest that the subsurface $P$ transport rate of alluvial floodplains with one PFP in the Ozark ecoregion may be at least $0.01-0.10 \mathrm{~kg}_{\text {year }}-1$ and perhaps even higher in cases where the subsurface is connected to a larger source of $P$. While the source of $P$ in the groundwater at these well managed sites was limited to minimal surface $\mathrm{P}$ and P-laden stream water entering the alluvial aquifer, this research demonstrated that coarse gravel subsoils have a capacity to transport as much $P$ as the surface runoff (i.e., the Barren Fork Creek site). The field data used in this analysis did not include floodplains with poultry litter application or cattle production. Also, upland areas may contribute $P$ to these floodplains through P-laden surface runoff or from the subsurface through karst features typical of the Ozark ecoregion. Further work is needed to quantify $\mathrm{P}$ transport in cases with such additional P sources.

\section{Conclusions}

Research has shown that subsurface P contributions can be significant in riparian zone soils with spatial variability in hydraulic conductivity, preferential flow pathways, and limited sorption capacity. This study estimated subsurface $P$ transport rates as quantified by annual $P$ rates crossing a transect within two groundwater systems, with uncertainty parameters quantified through Monte Carlo simulation. The subsurface $\mathrm{P}$ transport rate was compared to surface runoff rates based on simulations of PPM Plus. Results suggested that the subsurface $\mathrm{P}$ transport rates were significant compared to surface runoff $P$ rates at low intensity agricultural field sites. Though the subsurface contributions were small compared to the PPM Plus simulations with more intensive land use, floodplains with poultry litter application or cattle grazing may have a corresponding increase in subsurface P transport. The field sites in this study had low agricultural intensity; therefore, the calculated subsurface $P$ transport included a minimal amount of $\mathrm{P}$ leaching from the surface. Future work needs to quantify $\mathrm{P}$ leaching through the soil from a surface $P$ source and determine whether this significantly elevates levels of subsurface P transport. It is also hypothesized that as stream order increases, the significance of subsurface $P$ transport rate and preferential flow pathways increase.

\section{Acknowledgments}

This material is based upon work supported by the U.S. Environmental Protection Agency Region VI, Oklahoma Conservation Commission, Oklahoma Agricultural Experiment Station, and Oklahoma State University College of Agricultural Sciences and Natural 
Resources. The authors acknowledge Mr. Dan Butler and Mr. Bill Berry for providing access to the alluvial floodplain property. Amanda K. Fox, Stillwater, OK, is acknowledged for her assistance with the MATLAB software. We acknowledge Dr. Chad Penn, Oklahoma State University, for assistance with analysis of phosphorus data, and Dr. Todd Halihan, Oklahoma State University, for assistance with the electrical resistivity surveying. The authors also acknowledge Grant Graves, Katie Beitz, Jorge Guzman, and Jesi Lay, Biosystems and Agricultural Engineering, and Elliot Rounds, Plant and Soil Sciences, Oklahoma State University, for assisting with field and laboratory work.

\section{References}

Andrews, W.J., Becker, M.F., Smith, S.J., Tortorelli, R.L., 2009. Summary of SurfaceWater Quality Data from the Illinois River Basin in Northeast Oklahoma, 1970-2007. Scientific Investigations Report 2009-5182. U.S. Geological Survey, Reston, VA.

Arnold, J.G., Srinivasan, R., Muttiah, R.S., Williams, J.R., 1998. Large area hydrologic model development and assessment part 1: model development. J. Am. Water Resour. Assoc. 34, 73-89.

Carlyle, G.C., Hill, A.R., 2001. Groundwater phosphate dynamics in a river riparian zone: effects of hydrologic flow paths, lithology, and redox chemistry. J. Hydrol. 247, 151-168.

Cooper, A.B., Smith, C.M., Smith, M.J., 1995. Effects of riparian set-aside on soil characteristics in an agricultural landscape: implications for nutrient transport and retention. Agric. Ecosyst. Environ. 55, 61-67.

Crowder, B., Young, C.E., 1988. Managing Farm Nutrients: Tradeoffs for Surface and Ground Water Quality. Agricultural Economic Report no. 583. USDA, Washington, DC.

Daniel, T.C., Sharpley, A.N., Lemunyon, J.L., 1998. Agricultural phosphorus and eutrophication: a symposium overview. J. Environ. Qual. 27, 251-257.

Djodjic, F., Katarina, B., Bergstrom, L., 2004. Phosphorus leaching in relation to soil type and soil phosphorus content. J. Environ. Qual. 33, 678-684.

Fox, G.A., Munoz-Carpena, R., Sabbagh, G.J., 2010. Influence of flow concentration on parameter importance and prediction uncertainty of pesticide trapping by vegetative filter strips. J. Hydrol. 384, 164-173.

Fuchs, J.W., Fox, G.A., Storm, D.E., Penn, C., Brown, G.O., 2009. Subsurface transport of phosphorus in riparian floodplains: influence of preferential flow paths. J. Environ. Qual. 38, 473-484.

Gachter, R., Ngatiah, J.M., Stamm, C., 1998. Transport of phosphate from soil to surface waters by preferential flow. Environ. Sci. Technol. 32, 1865-1869.

Haan, C.T., Barfield, B.J., Hayes, J.C., 1994. Design Hydrology and Sedimentology for Small Catchments. Academic Press Inc., London, England.

Halihan, T., Paxton, S., Graham, I., Fenstemaker, T., Riley, M., 2005. Post-remediation evaluation of a LNAPL site using electrical resistivity imaging. J. Environ. Model. 7, 283-287.

Heathwaite, A.L., Dils, R.M., 2000. Characterizing phosphorus loss in surface and subsurface hydrological pathways. Sci. Total Environ. 251-252, 523-538.

Heeren, D.M., Miller, R.B., Fox, G.A., Storm, D.E., Halihan, T., Penn, C.J., 2010. Preferential flow effects on subsurface contaminant transport in alluvial floodplains. Trans. ASABE 53, 127-136.

Heeren, D.M., Fox, G.A., Miller, R.B., Storm, D.E., Mittelstet, A.R., Fox, A.K., Penn, C.J., Halihan, T. Stage-dependent transient storage of phosphorus in alluvial floodplains. Hydrol. Process., doi:10.1002/hyp.8054, in press.

Kleinman, P.J.A., Needelman, B.A., Sharpley, A.N., McDowell, R.W., 2004. Using soil phosphorus profile data to assess phosphorus leaching potential in manured soils. Soil Sci. Soc. Am. J. 67, 215-224.

Lacas, J.-G., Voltz, M., Gou, V., Carluer, N., Gril, J.-J., 2005. Using grassed strips to limit pesticide transfer to surface water: a review. Agron. Sustain. Dev. 25, 253-266.

McCarty, G., Angier, J., 2001. Impact of Preferential Flow Pathways on Ability of Riparian Wetlands to Mitigate Agricultural Pollution. American Society of Agricultural and Biological Engineers, St. Joseph, MI, ASAE Publication No. 701P0006.

McKay, M.D., 1995. Evaluating Prediction Uncertainty. NUREG/CR-6311. US Nuclear Regulatory Commission and Los Alamos National Laboratory, Los Alamos, NM.

Miller, R.B., Heeren, D.M., Fox, G.A., Halihan, T., Storm, D.E., Mittelstet, A.R., 2010. Geophysical Mapping of Preferential Flow Paths Across Multiple Floodplains. ASABE Paper No. 1008730. American Society of Agricultural and Biological Engineers, St. Joseph, MI.

Miller, R.B., Heeren, D.M., Fox, G.A., Storm, D.E., Halihan, T. Design and application of a direct-push vadose zone gravel permeameter. Ground Water, doi:10.1111/j.1745-6584.2010.00796.x, in press.

Murphy, J., Riley, J.P., 1962. A modified single solution method for the determination of phosphate in natural waters. Anal. Chim. Acta 27, 31-36.
Neitsch, S.L., Arnold, J.G., Kiniry, R., Srinivasan, R., Williams, J.R., 2002. Soil and Water Assessment Tool User's Manual, Version 2000 Grassland, Soil and Water Research Laboratory. Agricultural Research Service, Temple, TX.

Nelson, N.O., Parsons, J.E., Mikkelson, R.L., 2005. Field-scale evaluation of phosphorus leaching in acid sandy soils receiving swine waste. J. Environ. Qual. 34, 2024-2035.

NRCS (Natural Resource Conservation Service), 2009. National Agricultural Imagery Program Mosaic: 2008. Datagateway Database. USDA, Washington, DC, Available at: http://datagateway.nrcs.usda.gov/GatewayHome.html.

Pellerin, L., 2002. Applications of electrical and electromagnetic methods for environmental and geotechnical investigations. Surv. Geophys. 23, $101-132$.

Poletika, N.N., Coody, P.N., Fox, G.A., Sabbagh, G.J., Dolder, S.C., White, J., 2009. Chlorpyrifos and atrazine removal from runoff by vegetated filter strips: experiments and predictive modeling. J. Environ. Qual. 38, 1042-1052.

Polyakov, V., Fares, A., Ryder, M.H., 2005. Precision riparian buffers for the control of nonpoint-source pollutant loading into surface water: a review. Environ. Rev. $13,129-144$.

Popov, V.H., Cornish, P.S., Sun, H., 2005. Vegetated biofilters: the relative importance of infiltration and adsorption in reducing loads of water-soluble herbicides in agricultural runoff. Agric. Ecosyst. Environ. 114, 329-347.

Pote, D.H., Daniel, T.C., DeLaune, P.B., 2009. Total phosphorus and total dissolved phosphorus in water samples. In: Kovar, J.L., Pierzynski, G.M. (Eds.), Methods of Phosphorus Analysis for Soils, Sediments, Residuals, and Waters. SERA-IEG 17, Virginia Tech University, Blacksburg, VA, pp. 113-114.

Reichenberger, S., Bach, M., Skitschak, A., Frede, H.-G., 2007. Mitigation strategies to reduce pesticide inputs into ground- and surface water and their effectiveness: a review. Sci. Total Environ. 384, 1-35.

Robinson, D.A., Binley, A., Crook, N., Day-Lewis, F.D., Ferré, T.P.A., Grauch, V.J.S., Knight, R., Knoll, M., Lakshmi, V., Miller, R., Nyquist, J., Pellerin, L., Singha, K., Slater, L., 2008. Advancing process-based watershed hydrological research using near-surface geophysics: a vision for, and review of, electrical and magnetic geophysical methods. Hydrol. Process. 22, 3604-3635.

Romeis, J.J., Jackson, C.R., Risse, L.M., Sharpley, A.N., Radcliffe, D.E., 2011. Hydrologic and phosphorus export behavior of small streams in commercial poultrypasture watersheds. J. Am. Water Res. Assoc. 47, 367-385.

Sabbagh, G.J., Fox, G.A., Kamanzi, A., Roepke, B., Tang, J.Z., 2009. Effectiveness of vegetative filter strips in reducing pesticide loading: quantifying pesticide trapping efficiency. J. Environ. Qual. 38, 762-771.

Sharpley, A.N., Daniel, T., Sims, T., Lemunyon, J., Stevens, R., Parry, R., 2003. Agricultural Phosphorus and Eutrophication, second ed. USDA, Washington, DC, ARS-149.

Sims, J.T., Simard, R.R., Joern, B.C., 1998. Phosphorus loss in agricultural drainage: historical perspective and current research. J. Environ. Qual. 27, 277293.

Sims, J.T., Sharpley, A.N., 2005. Phosphorus: Agriculture and the Environment Agronomy Monograph No. 46. ASA-CSSA-SSSA, Madison, WI.

Soil Conservation Service, 1972. Hydrology. In: Section 4, Soil Conservation Service National Engineering Handbook. USDA, Washington, DC.

Stamm, C., Flühler, H., Gächter, R., Leuenberger, J., Wunderli, H., 1998. Preferential transport of phosphorus in drained grassland soils. J. Environ. Qual. 27, 515-522.

Storm, D.E., White, M.J., Smolen, M.D., Zhang, H., Gibson, T., 2007. Monitoring Edge of Field P Loss to Validate P Loss Index for the Spavinaw Creek Watershed: Final report submitted to the Oklahoma Conservation Commission. November 29, 2007. Biosystems and Agricultural Engineering Department, Oklahoma State University, Stillwater OK.

Storm, D.E., Busteed, P.R., Mittelstet, A.R., White, M.J., 2010. Hydrologic modeling of the Oklahoma/Arkansas Illinois River basin using SWAT 2005: Final report submitted to the Oklahoma. Department of Environmental Quality. Submitted October 8, 2009. Biosystems and Agricultural Engineering Department, Oklahoma State University, Stillwater, OK.

Thompson, C.A., McFarland, A.M.S., 2010. Effects of surface and groundwater interactions on phosphorus transport within streambank sediments. J. Environ. Qual. 39, 548-557.

Turner, B.L., Haygarth, P.M., 2000. Phosphorus forms and concentrations in leachate under four grassland soil types. Soil Sci. Soc. Am. J. 64, 1090-1099.

Vanek, V., 1993. Transport of groundwater-borne phosphorus to Lake Bysjon, South Sweden. Hydrobiologia 251, 211-216.

White, M.J., Storm, D.E., Smolen, M.D., Zhang, H., 2009. Development of a quantitative pasture phosphorus management tool using the SWAT model. J. Am. Water Resour. Assoc. 45, 397-406.

White, M.J., Storm, D.E., Busteed, P.R., Smolen, M.D., Zhang, H., Fox, G.A., 2010. A quantitative phosphorus loss assessment tool for agricultural fields. Environ. Model. Softw. 25, 1121-1129.

Zhang, H., Hamilton, D.W., Payne, J., 2009. Using Poultry Litter as Fertilizer. Oklahoma Cooperative Extension Service PSS-2246. Oklahoma State University, http://www.poultrywaste.okstate.edu/files/pss-2246web.pdf. 